\title{
UJI ADAPTASI VARIETAS UNGGUL BARU PADI SAWAH UNTUK OPTIMASI LAHAN TADAH HUJAN BERWAWASAN LINGKUNGAN DI KABUPATEN SELUMA PROVINSI BENGKULU
}

\author{
Yartiwi $^{1)}$, Atra Romeida ${ }^{2)}$, Satria Putra Utama ${ }^{3)}$ \\ 1) BPTP Balitbangtan Provinsi Bengkulu \\ 2) Jurusan Agroekoteknologi Fakultas Pertanian UNIB \\ 3) Jurusan Agribisnis Fakultas Pertanian UNIB
}

\begin{abstract}
ABSTRAK
Penggunaan varietas adaptif terhadap agroekosistem sangat penting dalam usaha budidaya padi dilahan sawah tadah hujan. Tujuan penelitian adalah untuk memperoleh varietas yang adaptif di lokasi pengujian berdasarkan keragaan pertumbuhan yang dicapai masing-masing varietas. Penelitian dilaksanakan pada bulan Oktober 2017 - Maret 2018 di Desa Karang Dapo Kecamatan Semidang Alas Maras Kabupaten Seluma Provinsi Bengkulu, di Laboratorium Tanah BPTP Bengkulu dan di Laboratorium Balai Besar Pasca Panen. Penelitian ini menggunakan rancangan acak kelompok (RAK) dengan 2 faktor. Faktor pertama adalah perlakuan varietas (V) yang terdiri dari 5 taraf perlakuan. Faktor kedua adalah paket pupuk (P) yang terdiri dari 2 taraf, sehingga diperoleh 10 kombinasi perlakuan. Setiap kombinasi perlakuan diulang sebanyak 3 kali. Jumlah tanaman sampel 10 tanaman/ulangan. Hasil Penelitian bahwa varietas Inpari 38, Inpari 39, Inpari 41 dan Situbagendit adaptif pada lingkungan biologi dan kimia dengan penggunaan rekomendasi pemupukan PUTS dan Katam pada lahan sawah tadah hujan di Desa Karang Dapo Kecamatan Semidang Alas Maras Kabupaten Seluma Provinsi Bengkulu.
\end{abstract}

Kata Kunci: VUB, Padi Sawah, Lahan Tadah Hujan

\section{PENDAHULUAN}

Provinsi Bengkulu memiliki lahan sawah seluas 91.651,4 ha dengan rincian sawah irigasi $64.093,7$ ha $(70 \%)$, sawah tadah hujan $22.320,3$ ha $(24,4 \%)$, pasang surut 1.249 ha $(1,4 \%)$ dan rawa lebak $3.988,4$ ha $(4,4 \%)$ (BPS Provinsi Bengkulu, 2016). Kabupaten Seluma sawah tadah hujan seluas yaitu 6.266 ha.

Produktivitas padi pada lahan sawah tadah hujan pada umumnya masih rendah, karena terbatasnya air untuk kebutuhan pertumbuhan tanaman padi tersebut. Lahan sawah tadah hujan sumber pengairannya tergantung dengan curah hujan, dicirikan dengan tidak adanya bangunan irigasi permanen. Posisinya berada pada wilayah yang tidak memungkinkan terjangkau oleh irigasi sehingga penanaman padi dan tanaman pangan semusim lainnya dilakukan satu kali dalam satu tahun (Kementan, 2017).

Budidaya padi pada lahan tadah hujan mempunyai resiko yang cukup tinggi. Kekurangan pasokan air dan ketidakseimbangan kandungan unsur hara merupakan permasalahan utama. Keracunan besi menyebabkan produktivitas padi relatif rendah (1-2 t/ha) atau bahkan tidak menghasilkan. Ada beberapa cara untuk mengatasi 
permasalahan tersebut yaitu penanaman varietas yang toleran dan pemupukan yang berimbang untuk meningkatkan keseimbangan unsur hara. Beberapa varietas padi lahan tadah hujan dan lahan kering telah dilepas oleh Badan Litbang Pertanian diantaranya adalah Inpari 38, 39, 40, 41, Situbagendit, Inpago 1, 2, 3, 4, 5, 6, 7 dan 8.

Hasil penelitian Setyorini, et al., (2011), bahwa Tiga varietas unggul baru yaitu Inpari 1, Conde, dan Dodokan berpotensi untuk dikembangkan sebagai varietas padi sawah selain IR64 pada musim kemarau (MK) di wilayah Desa Kebon Agung, Kecamatan Imogiri bahwa Inpari 1 menjadi varietas unggul baru yang mampu tumbuh dan beradaptasi dengan baik yaitu 11,64 t/ha

GKP hal ini menunjukkan Inpari 1 toleran terhadap kekeringan. Penggunaan varietas yang adaptif dan spesifik lokasi sangat diperlukan dalam mendukung peningkatan produktivitas dan produksi tanaman pangan di Provinsi Bengkulu. Untuk dapat menunjukkan potensi hasilnya, varietas padi memerlukan kondisi lingkungan atau agroekosistem tertentu (Rubiyo, et al., 2005). Tidak semua varietas mampu tumbuh dan berkembang pada berbagai agroekosistem. Dengan kata lain, tiap varietas akan memberikan hasil yang optimal jika ditanam pada lahan yang sesuai (Kustiyanto, 2001).

Upaya untuk memperbaiki produksi tanaman dan mempertahankan produktivitas dapat juga dilakukan dengan memenuhi kebutuhan hara tanah secara seimbang atau biasa disebut dengan pemupukan berimbang. Permasalahan selama ini di tingkat petani adalah pemberian pupuk masih belum sesuai dengan rekomendasi sehingga diperlukan kajian-kajian yang spesifik lokasi. Rekomendasi pemupukan dapat diperoleh dengan menggunakan uji laboratorium, Perangkat Uji Tanah Sawah (PUTS) atau Kalender Tanam (KATAM) Terpadu.
Tujuan penelitian ini adalah sebagai berikut untuk memperoleh varietas yang adaptif di lokasi pengujian berdasarkan keragaan pertumbuhan dan hasil serta produksi yang dicapai masing-masing varietas

\section{METODE PENELITIAN}

Penelitian telah dilaksanakan pada bulan Oktober 2017 - Maret 2018 di Desa Karang Dapo Kecamatan Semidang Alas Maras Kabupaten Seluma Provinsi Bengkulu. Penelitian ini menggunakan rancangan acak kelompok (RAK) dengan 2 faktor. Faktor pertama adalah perlakuan varietas (V) yang terdiri dari 4 varietas tanaman padivyaitu : V1 =Inpari 38, V2 = Inpari 39, V3 = Inpari 41, V4 = Situbagendit dan V5 Ciherang. Faktor kedua adalah paket rekomendasi pupuk (P) yang terdiri dari $\mathrm{P} 1=$ paket rekomendasi pupuk hasil analisis tanah menggunakan PUTS (NPK Phonska 150 kg/ha dan Urea $100 \mathrm{~kg} / \mathrm{ha})$ dan $\mathrm{P} 2=$ paket pupuk menggunakan rekomendasi Kalender Tanam (Katam) Terpadu MK 207/2018 Kecamatan Semidang Alas Maras (NPK Phonska $200 \mathrm{~kg} / \mathrm{ha}$ dan Urea $150 \mathrm{~kg} / \mathrm{ha}$ ), sehingga diperoleh 10 kombinasi perlakuan. Setiap kombinasi perlakuan diulang sebanyak 3 kali. Total unit percobaan sebanyak 30 unit.

Tahapan penelitian : pengolahan lahan, persemaian, penanaman, pemupukan, penyiangan, pengendalian hama dan penyakit dan panen. Variabel pengamatan pertumbuhan vegetatif lingkungan kimia (status hara dalam tanah dan dalam tanaman).

Analisis dilakukan terhadap data kuantitatif pengamatan dari variabel komponen pertumbuhan vegetatif dan generative menggunakan uji $\mathrm{F}$ pada taraf 5 $\%$. Apabila terdapat beda nyata antar perlakuan dilakukan uji lanjut dengan uji LSD taraf $5 \%$ menggunakan sofwere SX8. 


\section{HASIL DAN PEMBAHASAN}

\section{Gambaran Umum Lokasi Penelitian}

Luas lahan sawah menurut penggunaannya di wilayah Kabupaten Seluma yaitu 18.118 ha yang terdiri dari sawah irigasi seluas 10.126 ha, tadah hujan yaitu 6.266 ha, pasang surut 695 ha, dan lahan lebak seluas 1.031 ha (BPS Provinsi Bengkulu, 2016). Dari 14 kecamatan yang tersebar di Kabupaten Seluma, luas sawah tadah hujan yaitu 6.266 ha (BP3K Kecamatan Semidang Alas Maras, 2017).

Produktivitas di berbagai Kecamatan di Kabupaten Seluma masih banyak dibawah 6 t/ha bahkan masih banyak juga dibawah rata-rata produktivitas Kabupaten Seluma, dimana rata-rata produktivitas Kabupaten Seluma 4,94 t/ha. Kecamatan Semidang Alas Maras merupakan lokasi pelaksanaan penelitian dimana capaian produktivitasnya baru mencapai 4,6 t/ha. Sedangkan produktivitas di Desa Karang Dapo sendiri masih $3 \mathrm{t} / \mathrm{ha}$.

\section{Pertumbuhan Tanaman Tinggi Tanaman}

Hasil pengukuran pertumbuhan tinggi tanaman padi varietas Inpari 38, Inpari 38, Inpari 41, Situbagendit dan Ciherang dari umur 2 MST, 4 MST, 6 MST dan 8 MST disajikan pada Gambar 1.

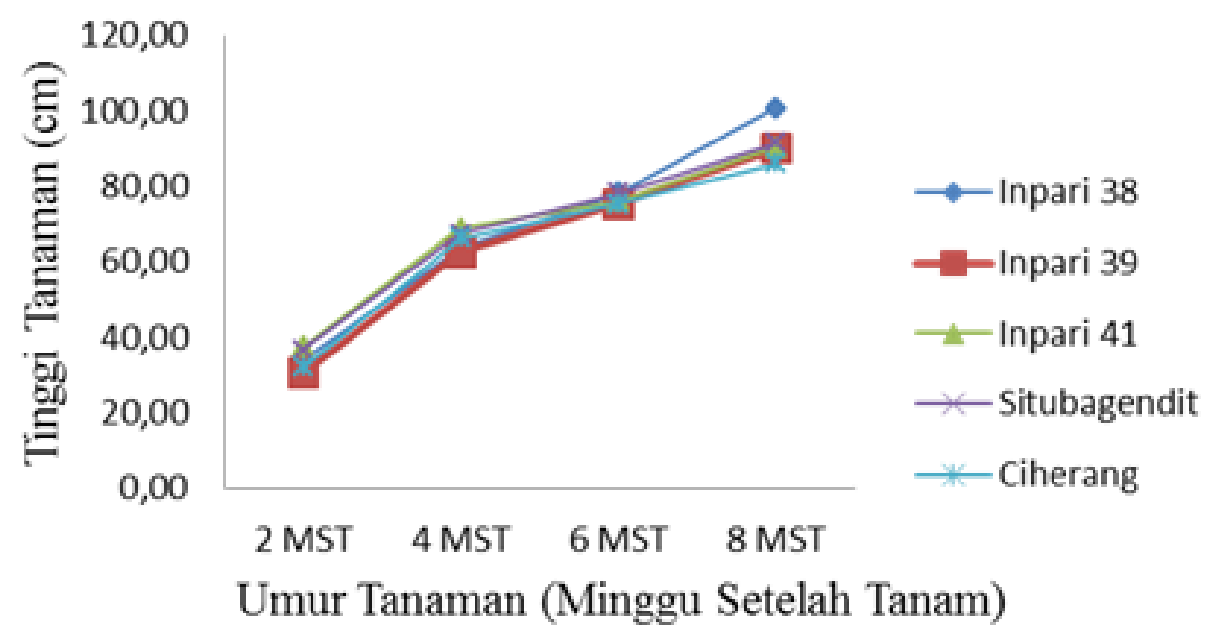

\section{Gambar 1. Pertumbuhan tinggi tanaman 5 varietas tanaman padi pada umur 2 MST, 4 MST, 6 MST dan 8 MST}

Gambar 1 menunjukkan bahwa 5 varietas tanaman padi yang ditanam pada umur 2 MST, 4 MST dan 6 MST tinggi tanaman belum menunjukkan perbedaan yang signifikan, namun pada umur 8 MST varietas Inpari 38 terlihat tinggi tanaman yang dihasilkan berbeda dengan varietas lain. Pertumbuhan tinggi tanaman ini berkorelasi positif dengan waktu dimana dengan umur tanaman bertambah maka tinggi tanaman juga bertambah. Dari grafik ini dapat dilihat bahwa varietas yang diujikan Inpari 38, Inpari 39, Inpari 41 dan Situbagedit lebih adaptif dalam melakukan pertumbuhan tinggi tanaman dibandingkan dengan varietas yang biasa ditanam petani.

Hasil pengukuran parameter tinggi tanaman kelima varietas yang diuji yang tertinggi umur 8 minggu yaitu varietas Inpari 38 dengan rata-rata $100,70 \mathrm{~cm}$, sedangkan tinggi tanaman yang paling rendah varietas Ciherang yaitu rata-rata 86,10 $\mathrm{cm}$.

\section{Jumlah Anakan}

Hasil pengukuran jumlah anakan varietas tanaman padi Inpari 38, Inpari 38, Inpari 41, Situbagendit dan Ciherang dari 
umur 2 MST, 4 MST, 6 MST dan 8 MST disajikan pada Gambar 2.

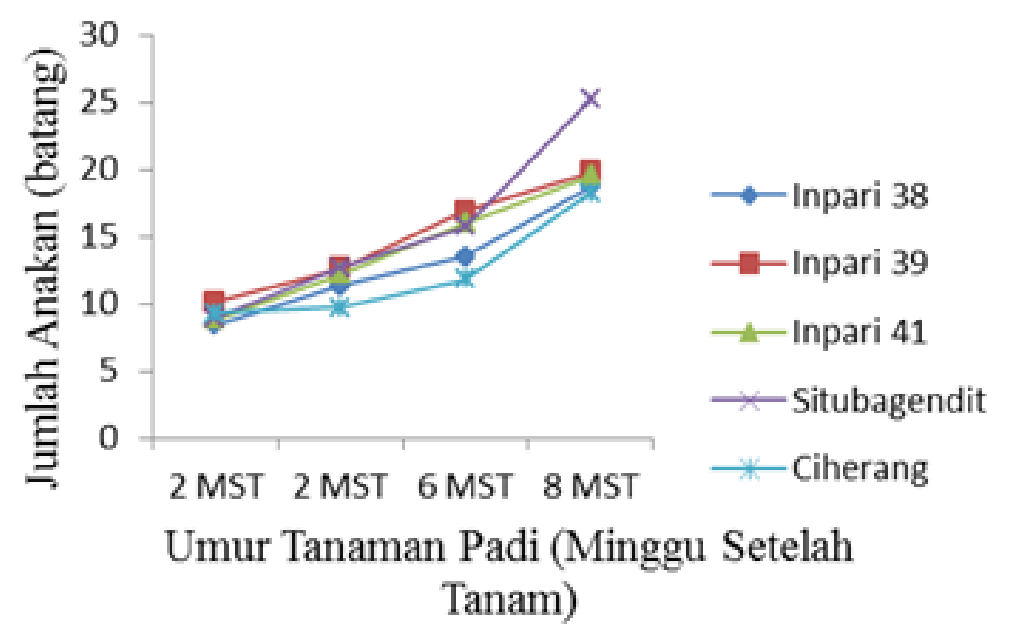

\section{Gambar 2. Jumlah Anakan 5 varietas tanaman padi pada umur 2 MST, 4 MST, 6 MST dan 8 MST}

Gambar 2 tersebut dapat dilihat bahwa tren pertambahan jumlah anakan semua varietas tumbuh normal dan tidak berbeda antara varietas Inpari 38, Inpari 39, Inpari 41 dan Ciherang namun pada varietas Situbagendit jumlah anakan pada umur 8 MST pertumbuhannya berbeda dengan varietas lain. Jumlah anakan yang paling banyak yaitu varietas Situbagendit dengan rata-rata jumlah anakan 25,2 batang sedangkan yang paling sedikit varietas $\mathrm{Ci}$ herang dengan rata-rata jumlah anakan 18,2 batang.

Penelitian ini dilakukan pada musim kemarau, namun pertumbuhan vegetatif masih normal dan rata-rata cukup adaptif terhadap lingkungan tumbuh yang diujikan, hal ini sesuai dengan keunggulan dari varietas yaitu toleran terhadap kekeringan sehingga masih bisa beradaptasi dengan baik di lokasi penelitian yaitu sawah tadah hujan hal ditunjukkan dari tinggi tanaman kelima varietas yang diuji umur 8 minggu antara $86,10-100,70 \mathrm{~cm}$ dan jumlah anakan berkisar 18,2-25,2 batang. Dilihat dari pertumbuhan tinggi tanaman varietas Inpari 38 sangat adaptif karena tinggi tanaman Inpari 38 yang diuji melebihi dari tinggi tanaman yang ada di deskripsi varietas yaitu $94 \mathrm{~cm}$ dibanding- kan 4 varietas lain kurang adaptif bila dilihat dari tinggi tanaman masih dibawah tinggi tanaman yang ada di deskripsi varietas.

Tinggi tanamanan ditentukan oleh kecepatan perpanjangan batang dan daun. Besarnya kecepatan perpanjangan tersebut adalah disebabkan oleh tinggi atau rendahnya potensi air di daun atau tekanan turgiditas didaun. Variasi pasokan air selama fase vegetatif dan reproduktif menentukan status air di tanah dan tanaman. Jumlah anakan padi juga berkaitan dengan periode pembentukan phyllochron. Phyllochron adalah periode muncul satu sel batang, daun dan akar yang muncul dari dasar tanaman dan perkecambahan selanjutnya. Semakin tua bibit dipindah ke lapang, semakin sedikit jumlah phyllochron yang dihasilkan, sedangkan semakin muda bibit dipindahkan, semakin banyak jumlah phyllochron yang dihasilkan sehingga anakan yang dapat dihasilkan juga semakin banyak (Sunadi, 2008). Sedangkan pada saat pengkajian ini umur bibit yang ditanam yaitu antara 18-25 hari setelah semai (hss) dengan jumlah bibit perlubang tanam yaitu 2-3 tanaman, dengan kondisi tersebut jika kebutuhan air saat pembentukan anakan 
tercukupi maka akan terbentuk anakan yang banyak namun kondisi dilapangan setelah pelaksanaan penanaman jumlah air sangat kurang karena tidak terjadi hujan.

Rata-rata curah hujan pada bulan Oktober 2016 sampai bulan Januari 2017 yaitu rata-rata $390,25 \mathrm{~mm}$ dan jumlah hari hujan rata-rata 19,75 hari/bulan. Sedangkan curah hujan selama penelitian yaitu rata-rata $315,25 \mathrm{~mm}$ dan jumlah hari hujan rata-rata 16 hari/bulan lebih rendah dibanding musim tanam sebelumnya pada bulan yang sama (BP3K Kecamatan Semidang Alas Maras 2017). Provinsi Bengkulu terdapat dua musim yaitu musim hujan dan musim kemarau walaupun dimusim kemarau masih banyak terjadi hujan. Curah hujan yang baik untuk pertumbuhan tanaman padi yaitu rata-rata $200 \mathrm{~mm} / \mathrm{bulan}$ dengan sebaran hari hujan yang merata. Sedangkan pada saat penelitian jumlah curah hujan tinggi per bulannya namun sebaran hari hujan tidak merata, sehingga pada saat tanaman membutuhkan air untuk kelangsungan siklus hidupnya air tidak tersedia. Air dibutuhkan tanaman padi pada saat fase pertumbuhan vegetatif umur 0-60 hst, fase pertumbuhan generatif umur 60-90 hst dan fase pemasakan gabah umur 90-120 hst. Ketiga fase pertumbuhan ini membutuhkan air yang berbeda-beda.

\section{Adaptasi Lingkungan \\ 1. Status Hara Dalam Tanah}

Sebelum melakukan dan setelah penelitian tanah dianalisis dengan tujuan untuk mengetahui tingkat kesuburan tanah pada lokasi penelitian dan untuk mengetahui tingkat status hara dalam tanah dan serapan tanaman oleh pupuk yang diberikan sehingga analisis tanah dilakukan berdasarkan perlakuan. Hasil analisis tanah sebelum dan setelah penelitian disajikan pada Tabel 1.

Tabel 1. Hasil analisis tanah lokasi penelitian sebelum penelitian dan setelah pelaksanaan penelitian.

\begin{tabular}{|c|c|c|c|c|c|c|c|}
\hline \multirow{3}{*}{ No } & \multicolumn{3}{|l|}{ Sebelum Penelitian } & \multicolumn{4}{|c|}{ Setelah Penelitian } \\
\hline & \multirow[t]{2}{*}{ Jenis Analisis } & \multirow[t]{2}{*}{$\begin{array}{l}\text { Hasil } \\
\text { Analisi } \\
\left.\mathrm{s}^{*}\right)\end{array}$} & \multirow[t]{2}{*}{$\begin{array}{l}\text { Kriteria/St } \\
\text { atus } \\
\text { Hara }^{* *)}\end{array}$} & $\begin{array}{l}\text { Hasil } \\
\text { Analisis }\end{array}$ & $\begin{array}{l}\text { Kriteria/ } \\
\text { Status } \\
\left.\text { Hara }^{* *}\right)\end{array}$ & $\begin{array}{l}\text { Hasil } \\
\text { Analisi } \\
\text { s }^{*}\end{array}$ & $\begin{array}{l}\text { Kriteria/ } \\
\text { Status } \\
\text { Hara }^{* *}\end{array}$ \\
\hline & & & & Katam & & PUTS & \\
\hline 1. & C-Organik (\%) & 1,4 & Rendah & & & & \\
\hline 2. & N-Total (\%) & 0,29 & Sedang & 0,37 & Sedang & 0,25 & Sedang \\
\hline 3. & $\mathrm{C} / \mathrm{N}$ & 4,83 & Rendah & & & & \\
\hline 4. & P-Bray I (ppm) & 5,10 & Rendah & 0,17 & $\begin{array}{l}\text { Sangat } \\
\text { Rendah }\end{array}$ & 2,99 & Rendah \\
\hline 5. & $\mathrm{~K}-\mathrm{dd}(\mathrm{me} / 100 \mathrm{~g})$ & 0,29 & Rendah & 0,28 & Rendah & 1 & Rendah \\
\hline 6. & Ca-dd (me/100 g) & - & & & & & \\
\hline 7. & Mg-dd (me/100 g) & - & & & & & \\
\hline 8. & Na-dd (me/100 g) & 0,2 & Rendah & & & & \\
\hline 9. & KTK (me/100 g) & 10,91 & Rendah & & & & \\
\hline 10. & $\mathrm{pH} \mathrm{H} \mathrm{H}_{2} \mathrm{O}$ & 4,89 & Masam & 4,58 & Masam & 4,65 & Masam \\
\hline
\end{tabular}

*) Contoh tanah dianalisis di Laboratorium Tanah BPTP Bengkulu, 2017.

**) Pusat Penelitian Tanah (1983) 
Berdasarkan hasil analisis tanah itu (Tabel 1) dilihat bahwa tanaman mampu menyerap semua unsur hara yang diberikan dengan efisien karena unsur hara yang diberikan rata-rata terserap habis oleh tanaman atau kondisi tanah dikembalikan seperti sebelum melakukan penelitian bahkan ada perlakuan yang berlebih menyerap kandungan $\mathrm{P}$ dalam tanah yaitu pada perlakuan paket pupuk katam. Hal ini dapat dilihat sebelum penelitian status hara $\mathrm{P}$ dalam kriteria rendah menjadi sangat rendah sehingga dengan asumsi bahwa kandungan unsur hara $\mathrm{P}$ masih dapat ditingkatkan. Dari 2 paket rekomendasi pupuk yang diberikan tersebut dilihat dari lingkungan secara keseluruhan rekomendasi menggunakan PUTS yang lebih baik karena unsur hara yang tersisa dalam tanah lebih banyak dibandingkan paket pupuk rekomendasi Katam.

Hasil penelitian Kasno dan Rostaman (2011) bahwa hara $\mathrm{N}$ merupakan faktor pembatas pertumbuhan dan hasil padi pada lahan sawah tadah hujan. Pemupukan $\mathrm{N}$ secara nyata dapat meningkatkan pertumbuhan dan hasil padi berkisar antara 1,30 - 3,60 t/ha atau 30 -137\%.

\section{Status Hara Dalam Tanaman}

Hasil analisis kandungan unsur hara pada tanaman di umur 28 hst bahwa perlakuan penggunaan paket pupuk menggunakan rekomendasi PUTS dan rekomendasi Katam hanya varietas Inpari 41 kandungan $\mathrm{N}$ yang kriteria sedang yaitu $3,09 \%$ dan $2,72 \%$, namun secara seluruhan termasuk kriteria rendah yaitu 1,71 $\%$ dan $1,70 \%$. Untuk kandungan $\mathrm{P}$ dan $\mathrm{K}$ semua varietas kandungan unsur hara dalam tanaman termasuk kriteria tinggi. Hasil analisis selanjutnya yaitu pada umur $45 \mathrm{hst}$ semua kandungan unsur hara $\mathrm{N}$ pada lima varietas yang diujikan masuk kriteria rendah baik itu pada perlakuan penggunaan pupuk menggunakan PUTS maupun rekomendasi Katam, sedangkan kandungan P dan K semua termasuk kriteria tinggi.
Berdasarkan hasil analisis tanaman tersebut dapat dilihat unsur hara $\mathrm{N}$ rendah diduga disebabkan pada saat tanaman sedang aktif melakukan pertumbuhan vegetatif dan generatif sehingga energi untuk menyerap unsur hara $\mathrm{N}$ dalam tanah menjadi sangat rendah, sedangkan daya serap unsur hara $\mathrm{P}$ dan $\mathrm{K}$ sebaliknya. Sebagaimana kita ketahui umur 28 hst itu tanaman sedang memasuki fase vegetatif yang membutuhkan unsur hara $\mathrm{N}$ yang tinggi hal dilihat dari jumlah anakan yang terbentuk juga masih kurang, sedangkan pada umur 45 hst tanaman sudah memasuki fase generatif yang seharusnya tanaman juga harus banyak mengandung $\mathrm{N}$ karena unsur hara $\mathrm{N}$ ini merupakan dapur dari tanaman untuk mempertahankan hidup.

Rendahnya kandungan $\mathrm{N}$ pada tanaman ini diduga selain kemampuan varietas untuk mengambil unsur hara $\mathrm{N}$ dalam tanah kurang, bisa juga disebabkan unsur hara $\mathrm{N}$ dalam tanah itu sendiri kurang sehingga yang mau diserap tanaman memang tidak ada lagi atau sudah habis. Berdasarkan hasil analisis tersebut untuk dosis pupuk $\mathrm{N}$ masih bisa ditingkatkan lagi dari dosis perlakuan atau dengan penambahan bahan organik. Berdasarkan hasil penelitian Nuryani, et al (2010) bahwa penambahan bahan organik dapat menaikan $\mathrm{pH}$ tanah, meningkatkan KTK dan ketersediaan $\mathrm{N}, \mathrm{P}, \mathrm{K}$ tanah begitu juga dapat meningkatkan serapan hara $\mathrm{N}, \mathrm{P}, \mathrm{K}$ pada tanaman tersebut.

\section{KESIMPULAN}


Berdasarkan pertumbuhan vegetatif dan generatif varietas Inpari 38, Inpari 39, Inpari 41 dan Situbagendit adaptif pada lahan sawah tadah hujan di Desa Karang Dapo Kecamatan Semidang Alas Maras Kabupaten Seluma Provinsi Bengkulu.

\section{DAFTAR PUSTAKA}

Badan Pusat Statistik. 2016. Provinsi Bengkulu Dalam Angka. Bengkulu.

BP3K Kecamatan Semidang Alas Maras 2017. Programa BPP Kecamatan Semidan Alas Maras. Kabupaten Seluma. Provinsi Bengkulu

Kasno. A dan T. Rostaman. 2011. Respon tanaman padi terhadap pemupukan $\mathrm{N}$ pada lahan sawah tadah hujan. Jural Penelitian Pertanian Tanaman Pangan Vol 1 (3) : 10 hal

Kementerian Pertanian. 2017. Petunjuk Teknis "Implementasi Infrastruktur Panen Air" Badan Penelitian dan Pengembangan Pertanian. Jakarta.

Kustyanto. 2001. Kriteria seleksi untuk sifat toleran cekaman lingkungan biotik dan abiotik. Makalah penelitian dan koordinasi pemuliaan partisipatif (Shuttle Breeding) dan Uji multilokasi. Sukamandi.

Nuryani. S.H.U., Haji. M dan N. Widya. 2010. Serapan hara N, P, K pada pada tanaman padi dengan berbagai lama penggunaan penggunaan pupuk organik pada vertisol seragen. Jurnal Ilmu Tanah dan Lingkungan. Vol. 10 (1). $\mathrm{p}: 1$-13.

Rubiyo, Suprapto, dan Aan Drajat. 2005. Evluasi beberapa galur harapan padi sawah di Bali. Buletin Plasma Nutfah. Vol 11. No 1:6-10.

Setyorini, W., Kristamtini dan Sutarno. 2011. Daya Hasil Tiga Varietas Unggul Baru Padi Sawah Di Kebon Agung - Bantul. Widyariset, Vol. 14 (3). $559-563 p$

Sunadi. 2008. Modifikasi paket teknologi SRI (The System or Rice Intensification) untuk meningkatkan hasil padi (Oryza sativa. L) sawah. ). Disertasi Doktor Ilmu Pertanian pada Progam Pascasarjanan Unand. Padang. 